Jurnal IImiah Iqra'

2541-2108 [Online] 1693-5705 [Print]

Tersedia online di: http://journal.iain-manado.ac.id/index.php/JII

\title{
Konsep Etika Guru Perspektif Al-Bukhari; Studi atas Kitab Sahih al-Bukhari Karya Abu 'Abdillah Muhammad bin Ismail al- Bukhari
}

\author{
Ahmad Junaedy Abuhuraerah \\ IAIN Manado, Manado, Indonesia \\ wahabon@gmail.com
}

\begin{abstract}
Abstrak
Tulisan ini bertujuan mengangkat suatu kajian hadits tentang konsep guru ideal yang ditawarkan oleh Muhammad bin Ismail al-Bukhari dalam kitab Sahihnya, dan konsep ini sangat relevan terhadap profesionalitas guru Pendidikan Agama Islam, yaitu dalam Undangundang No.14 Tahun 2005 tentang Guru dan Dosen. Adapun metode yang digunakan adalah library research dengan menerapkan teknik content analysis pada pembahasan etika guru perspektif al-Bukhari. Dan dari temuan peneliti, dapat disimpulkan bahwa dalam proses mengajar dibutuhkan etika yang baik, yaitu seorang guru harus memiliki sifat keikhlasan, berilmu, konsukuen, kasih sayang, memperhatikan keadaan peserta didik, penyabar, bersikap adil dan tidak diskriminatif dan bertanggungjawab. Dan hal ini relevan terhadap profesionalitas guru Pendidikan Agama Islam.
\end{abstract}

Kata kunci: Etika Guru; al-Bukhari

\begin{abstract}
The Concept of Teacher Ethics in Al-Bukhari's Perspective; Study of the Book of Sahih al-Bukhari by Abu 'Abdillah Muhammad bin Ismail al-Bukhari. This paper aims to discuss study of hadist about the concept of ideal teacher offered by Muhammad bin Ismail al-Bukhari in his book, Shahih al-Bukhari, and also relevant to the professionalism of Islamic Education Teacher in basic constitusion about teacher and lecturer No. 14 Tahun 2005. The method used is library research by applying content analysis technique in discussion of teacher's etihc in al-Bukhari's perspective. And the conclusion in this paper tahat is a teacher must have nature of sincerity, knowledge, concern, compassion, pay attention to student, patient, fair, no discriminating and responsible. And this relevant to the professionalism of Islamic education teacher.
\end{abstract}

Keywords: Teacher's Ethic; al-Bukhari 


\section{Pendahuluan}

Keberadaan guru dianggap sebagai orang yang bertanggungjawab terhadap perkembangan potensi dari peserta didiknya. Hal ini bisa dilaksanakan melalui berbagai upaya serius dan sistematis untuk mengembangkan kemampuan peseserta didiknya baik dalam bidang kognitif, psikomotorik, maupun psikomotoriknya (Tafsir, 2010). Dalam dimensi ini menunjukkan bahwa arti vital keberadaan guru sebagai salah satu bagian yang paling bertanggungjawab terhadap peserta didiknya untuk dapat mencapai tujuan pendidikan tersebut.

Para pakar sepakat menyebutkan bahwa guru merupakan orang yang memiliki tingkat kedewasaan sehingga mampu memberikan pengarahan dan bimbingan kepada peserta didiknya sehingga bertambah tingkat kedewasaannya (Daeng Pawero, 2018). Kedewasaan di sini bukan hanya diartikan bertambah usia peserta didik, namun lebih diartikan sebagai peningkatan dari aspek psikologis, emosional, dan intelegen daripada peserta didik.

Ibnu Suhnun (202-256 H/813-869 M), al-Qabisi (324-403 H/936-1012 M), alGhazali (450-505 H/ 1058-1111 M) dan Ibnu Jama'ah (639-733 H/1241-1333 M.) merupakan sederetan ulama pendidikan klasik yang memberikan perhatian serius mengenai etika guru. Sedangkan pakar pendidikan Islam era modern yang membahas etika guru antaranya adalah Hashim Ash'ari dan 'Abd al-Qadir. Semua mereka dalam karyanya masing-masing tampaknya sepakat bahwa seorang guru sejati mestilah menjaga dan berperilaku sesuai kode etik (Ash'ari, n.d.). Etika guru ditempatkan pada posisi yang sangat penting bukan hanya sebagai prasyarat dalam meraih kesuksesan dalam pembelajaran, tetapi juga guru yang mengamalkan atau berperilaku seseuai etika akan mempengaruhi kehidupan peserta didik.

Selain sederetan ulama pendidikan klasik dan pakar pendidikan Islam era modern yang memberikan perhatian serius mengenai etika guru, juga ulama pakar hadits mempunyai peran dan perhatian besar terhadap etika seorang guru melalui paparan hadits-hadits dari Rasulullah saw. Diantaranya adalah ulama hadits yang sangat popular dikalangan kaum muslimin adalah al-Imam al-Bukhari.

Tulisan ini memaparkan etika seorang guru dalam riwayat Imam al-Bukhari, diantara riwayat yang menyebutkan bahwa seorang guru mendapatkan kedudukan dan penghargaan sebagai al-'Ulamaa Waratsat al-Anbiyaa (pewaris para nabi) (AlTirmidzi, 1987). Dan untuk mencapai kedudukan tersebut, maka seorang guru harus memiliki etika sebagaimana yang disebutkan oleh Imam al-Bukhari, yaitu memiliki 
sifat keikhlasan, berilmu, konsukuen, kasih sayang, memperhatikan keadaan peserta didik, jujur dalam perkataan dan perbuatan, penyabar, tawādhu' (rendah hati), bersikap adil dan tidak pilih kasih dan bertanggungjawab. Dan konsep etika yang ditawarkan oleh Imam al-Bukhari tersebut direlevansikan dengan profesionalitas guru Pendidikan Agama Islam.

\section{Kajian Teori}

\section{Etika Guru dalam Pendidikan Islam}

Dalam sejarah pemikiran para Ulama dalam pendidikan Islam, banyak ditemukan khazanah mutiara pemikiran dalam ranah etika guru. Dimana etika ini di rumuskan oleh para Ulama pemikir pendidikan Islam untuk dijadikan pegangan bagi guru pada waktu itu. Namun demikian, bukan berarti sudah tidak relevan dengan masa sekarang, tetap saja pemikiran para Ulama tersebut dapat diaplikasikan oleh para guru di era sekarang ini. Diharapkan ketika guru menerapkan norma-norma tersebut akan dapat menjalankan profesinya dengan baik. Sehingga marwah guru akan tetap bisa terjaga dalam masyarakat, karena mereka memegang etik guru dalam perspektif Islam. Ada hal menarik terkait dengan etika guru dalam Islam. Karena dia dapat dijadikan sebagai pegangan norma yang harus dipatuhi oleh setiap guru. Hal ini menunjukan bahwa posisi guru begitu sangat penting sehingga ulama memberikan batasan etika lebih banyak dibandingkan dengan peserta didiknya.

Al-Ghazali memiliki pandangan bahwa etika yang harus dipatuhi oleh guru (pendidik) meliputi delapan hal, diantaranya: 1) kasih sayang dan lemah lembut; 2) tidak mengharap upah, pujian, ucapan terima kasih atau balas jasa; 3) jujur dan terpercaya bagi murid-muridnya; 4) membimbing dengan kasih sayang, tidak dengan marah; 5) luhur budi dan toleransi; 6) tidak merendahkan ilmu lain di luar spesialisasinya; 7) memerhatikan perbedaan individu; dan 8) konsisten (Al-Ghazali, 2005).

Ibnu Khaldun berpendapat bahwa seorang guru harus mempunyai etika dalam proses pembelajaran. Yaitu; 1) Adanya pemahaman dan pengulangan secara berproses; 2) Seorang guru dalam melaksanakan tugas kependidikannya harus mengerti psikologi murid-muridnya; 3) Dalam menyajikan materi pelajaran, hendaknya guru memfokuskan pada satu masalah, jangan mencampuradukan; 4) Dalam menyajikan materi pelajaran, hendaknya seorang guru jangan terlalu lama mengulur waktu sehingga menganggu jadwal belajar seharusnya; 5) Utamakan 
pemahaman pelajaran, jangan hanya hafalan; 6) Seorang guru hendaknya bersikap kasih sayang terhadap anak didiknya (Suyitno, 2006).

Dari penjelasan di atas dapat ditarik kesimpulan bahwa, sifat atau etika seorang guru terbagi tiga macam:

Pertama, sifat yang terkait dengan dirinya sendiri. Guru dalam bagian ini paling tidak memiliki dua sifat, yaitu: (1) sifat-sifat keagamaan (diniyah) yang baik, meliputi patut dan tunduk terhadap syariat Allah dalam bentuk ucapan dan tindakan; dan (2) sifat-sifat akhlak yang mulia (akhla-qiyah), seperti menghias diri (tahalli) dengan memeliharanya, khusyu', rendah hati, menerima apa adanya, zuhud, memiliki daya dan hasrat yang kuat dalam ilmunya.

Kedua, sifat terhadap peserta didiknya. Guru dalam bagian ini paling tidak memiliki tiga sifat, yaitu: (1) sifat-sifat sopan santun (adabiyah), yang terkait dengan akhlak yang mulia seperti di atas; (2) sifat-sifat memudahkan, menyenangkan dan menyelamatkan (muhniyah); dan (3) sifat kebapakan (abawiyah), dan yang terpenting sifat kasih sayang.

Ketiga, sifat dalam proses belajar-mengajar. Guru dalam bagian ini paling tidak mempunyai dua sifat, yaitu: (1) sifat-sifat memudahkan, menyenangkan dan menyelamatkan (muhniyah); dan (2) sifat-sifat seni, yaitu seni mengajar yang menyenangkan, sehingga peserta didik tidak merasa bosan.

\section{Metode}

Penelitian ini menggunakan pendekatan penelitian kualitatif dengan jenis penelitian kepustakaan (Library Research) yakni penelitian yang dilakukan dengan mengumpulkan data pustaka, membaca, mencatat, dan mengolah bahan untuk keperluan penelitian (Zed, 2008). Dalam penelitian ini, peneliti bertidak sebagai pengumpul data utama. Data yang diperoleh berasal dari data primer dan data sekunder. Data primer diperoleh dari Kitab Shahih Al-Bukhari karangan Imam AlBukhari dan data sekunder diperoleh dari rujukan pendukung. Adapun teknik analisi yang digunakan adalah content analysis atau analisis isi, di mana peneliti melakukan penafsiran isi terhadap teks hadist di dalam Kitab Shahih Al-Bukhari yang mengulas soal etika guru. 


\section{Hasil dan Pembahasan}

\section{Biografi Imam al-Bukhari}

Nama lengkapnya adalah Abu Abdillah Muhammad bin Ismail bin Ibrahim bin al-Mughirah al-Ju'fi. Beliau dilahirkan hari Jum'at, 13 Syawal 194 H di Bukhara. Ayahnya, Isma'il, adalah seorang ulama hadits pula yang berguru pada sejumlah ulama termasyhur, seperti Malik bin Anas, Hammad bin Zaid dan Ibn Mubarak. Ia meninggal ketika Bukhari masih kecil. Riwayat hidupnya ditulis oleh Ibn Hibban dalam kitab al-Tsiqah dan oleh putranya, Imam Bukhari dalam kitab al-Tarikh al-Kabir (Al-Subki, n.d.).

Bukhari memiliki daya hafalan yang tinggi sebagaimana yang diakui oleh saudara kandungnya, Rasyid bin 'Ismail. Sosok Bukhari kurus, tidak tinggi, tidak pendek, kulit agak kecoklatan, ramah, dermawan, dan banyak mendonasikan hartanya untuk pendidikan (Al-Subki, n.d.).

Bukhari tergolong hidup dalam keluarga terpandang. Di samping beliau anak dari seorang ulama yang disegani, secara ekonomis beliau juga tergolong anak orang kaya. Namun saat Bukhari remaja orang tuanya meninggal dunia.

Imam al-Bukhari mempelajari hadits pertama kali di kota kelahirannya Bukhara pada usia 10 tahun. Beliau sudah memahami benar ilmu hadits pada waktu beliau masih kecil. Disebutkan dalam al-Bidayah wa al-Nihayah bahwa al-Bukhari pada saat usianya masih belia sudah hafal 70 ribu hadits dengan sanad-sanadnya (AlSubki, n.d.).

Pada masa akhir hidupnya, Imam Bukhari banyak mengalami kekerasan dan dipaksa oleh pemerintah untuk meninggalkan negara-nya. Dan pada tahun $256 \mathrm{H}$, tepatnya tanggal 30 Ramadhan (malam 'Idul Fitri), Imam Bukhari dipanggil keharibaan Allah swt. Beliau wafat di daerah Khirtand, yaitu suatu daerah tidak jauh dari Samarkand (Soetari, 2008).

\section{Etika Guru Perspektif Imam al-Bukhari}

Tugas seorang guru tidak sebatas menyampaikan materi pelajaran kepada anak didik saja bahkan ia merupakan tugas yang berat dan sulit, tetapi akan mudah bagi siapa yang dimudahkan Allah swt. Tugas tersebut menuntut seorang pengajar bersifat sabar, amanah, ketulusan, dan mengayomi yang di bawahnya. Beberapa 
etika yang harus dimiliki oleh seorang guru, sebagaimana yang di paparkan oleh Imam al-Bukhari dalam beberapa riwayatnya yaitu:

1. Memiliki Sikap Keikhlasan

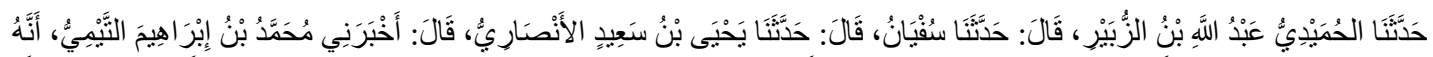

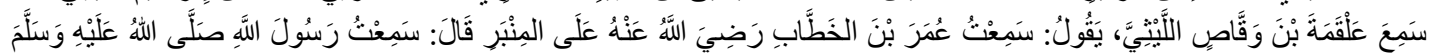

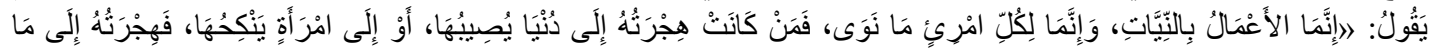
هَاجَرَ إلَيْهَ.

Terjemahan:

Telah menceritakan kepada kami [Al Humaidi Abdullah bin Az Zubair] dia berkata, Telah menceritakan kepada kami [Sufyan] yang berkata, bahwa Telah menceritakan kepada kami [Yahya bin Sa'id Al Anshari] berkata, telah mengabarkan kepada kami [Muhammad bin Ibrahim At Taimi], bahwa dia pernah mendengar [Alqamah bin Waqash Al Laitsi] berkata; saya pernah mendengar [Umar bin Al Khaththab] diatas mimbar berkata; saya mendengar Rasulullah shallallahu 'alaihi wasallam bersabda: "Semua perbuatan tergantung niatnya, dan (balasan) bagi tiap-tiap orang (tergantung) apa yang diniatkan; Barangsiapa niat hijrahnya karena dunia yang ingin digapainya atau karena seorang perempuan yang ingin dinikahinya, maka hijrahnya adalah kepada apa dia diniatkan" (M. bin I. bin I. al-M. Al-Bukhari, 2002)

Riwayat Muhammad bin Ismail al-Bukhari menjelaskan bahwa keikhlasan merupakan syarat diterimanya suatu amalan, dan suatu amalan tidak dikatakan amal shalih tanpa keikhlasan. Al-Khatthabi berkata, keabsahan amalan dan keberadaan konsekuensinya ditentukan oleh niatnya. Jadi, sesungguhnya niatlah yang mengarahkan amalan (Al-Khattabi, 1932). Senada apa yang disebutkan oleh Ibnu Hajar bahwa hadits tersebut terdapat penekanan disyariatkan niat dan ikhlas dalam setiap amalan (perbuatan) (Al-Asqalany, n.d.).

Kata ikhlas itu sendiri secara bahasa adalah derivasi dari kata - خَلَنَ - خُوْوَصًا إِخْلاصـا yang artinya murni, tiada bercampur, bersih, jernih (Munawir \& Al-Bisri, 1999). Berkaitan dengan kata ikhlas, Nawawi mengungkapkan bahwa, "Ikhlas yaitu membersihkan panca indranya dengan lahir dan batin dari budi pekerti yang tercela (Al-Bantani, n.d.).

Pentingnya sifat ikhlas ini, digambarkan juga oleh Ibnu al-Qayyim sebagai ruh (nyawa) dalam perbuatan, ikhlas adalah pemandu bagi perbuatan, menjadi pondasinya, dan orang yang melakukan suatu perbuatan yang tidak didasari dengan niat ikhlas, maka akan mendapatkan kehinaan (Al-Jawziyyah, n.d.). Adapun pandangan ulama tasawuf mengenai ikhlas, sebagaimana yang dikutip oleh al- 
Ghazali dalam kitabnya Ihya Ulum al-Din, bahwa ikhlas adalah membersihkan perbuatan dari kotoran (Al-Ghazali, 2005).

Jadi dapat disimpulkan bahwa ikhlas adalah mengerjakan suatu amal perbuatan semata-mata hanya untuk mendapatkan rida dari Allah swt. bukan untuk meraih pamrih duniawi, dengan tidak mengharapkan pujian dari manusia dan senantiasa menjaga niatnya dengan benar.Oleh karena itu, menjadi sangat penting diperhatikan bagi siapa saja yang bergelut dalam dunia keilmuan, baik para petualang ilmu maupun orang-orang yang mengajarkan ilmu (guru), agar mereka memiliki keikhlasan dalam dirinya.

2. Berilmu

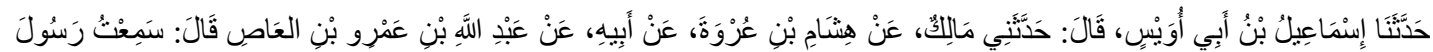

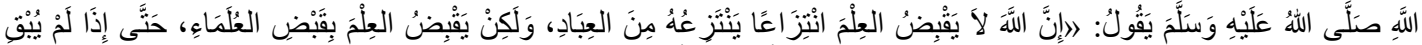

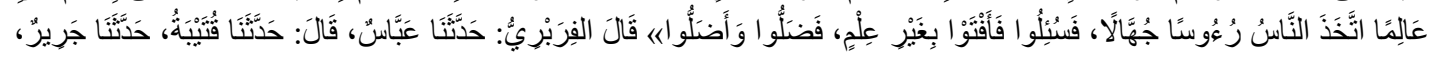

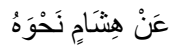

Terjemahan:

Telah menceritakan kepada kami [Isma'il bin Abu Uwais] berkata, telah menceritakan kepadaku [Malik] dari [Hisyam bin 'Urwah] dari [bapaknya] dari [Abdullah bin 'Amru bin Al 'Ash] berkata; aku mendengar Rasulullah shallallahu 'alaihi wasallam bersabda: "Sesungguhnya Allah tidaklah mencabut ilmu sekaligus mencabutnya dari hamba, akan tetapi Allah mencabut ilmu dengan cara mewafatkan para ulama hingga bila sudah tidak tersisa ulama maka manusia akan mengangkat pemimpin dari kalangan orang-orang bodoh, ketika mereka ditanya mereka berfatwa tanpa ilmu, mereka sesat dan menyesatkan". Berkata Al-Firabri Telah menceritakan kepada kami 'Abbas berkata, Telah menceritakan kepada kami Qutaibah Telah menceritakan kepada kami Jarir dari Hisyam seperti ini juga (M. bin I. bin I. al-M. Al-Bukhari, 2002).

Muhammad bin Ismail al-Bukhari menjelaskan bahwa orang yang berfatwa dan mengajar harus memiliki ilmu. Termasuk dalam hal ini ialah seorang guru, guru haruslah orang yang berilmu. Jika seorang guru tidak berilmu tentu peserta didik yang diajarnya akan sesat. Senada yang diucapkan oleh al-Hafizh Ibnu Abd al-Barr bahwa barangsiapa tidak berilmu dan menjawab pertanyaan yang diajukan kepadanya dengan tanpa ilmu, dan mengqias (membandingkan) dengan akalnya, sehingga mengharamkan apa yang Allah halalkan dengan kebodohan, dan menghalalkan apa yang Allah haramkan dengan tanpa dia ketahui, maka inilah orang yang mengqias dengan akalnya, sehingga dia sesat dan menyesatkan (Al-Barr, n.d.). 
Ini adalah ancaman yang sangat keras bagi seorang guru yang mendidik dan mengajarkan anak didiknya tanpa ilmu, karena dapatkan menyesatkan peserta didiknya. Hamzah Muhammad Qasim menjelaskan, mereka berfatwa tanpa ilmu, maksudnya ialah mereka berfatwa di atas kebodohan, mereka menghalalkan yang haram dan mengharamkan yang halal. "Maka mereka sesat" dalam diri mereka sendiri dari kebenaran. "Dan menyesatkan" orang yang mengikuti mereka dan mengambil fatwa mereka dari kalangan masyarakat awam.

Dengan demikian, berfatwa dan mengajar sama-sama memberi ilmu. Maka, berfatwa, mendidik dan mengajar tanpa ilmu akan menyesatkan orang lain. Oleh karena itu, seorang guru hendaklah selalu membekali dirinya dengan ilmu pengetahuan.

Maka, seorang guru hendaknya selalu belajar dan menambah ilmu pengetahuannya, tidak terpedaya dengan gelar akademik yang disandangnya sehingga ia meninggalkan belajar. Bahkan, seharusnya gelar-gelar tersebut memotivasi dirinya untuk selalu belajar dan menambah wawasan karena dia bertanggung jawab untuk mencerdaskan anak didiknya. Mustahil, dia mampu mencerdaskan orang lain dengan suatu ilmu pengetahuan, sedangkan ia sendiri tidak memiliki ilmu itu. Akibatnya psikologisnya terganggu, prilakunya menyimpang, dan kemampuan sosialnya yang lemah (Ulwan, 2008).

\section{Konsekuen}

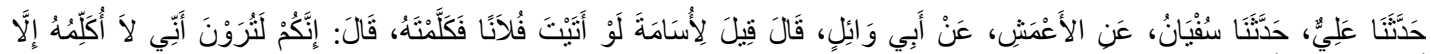

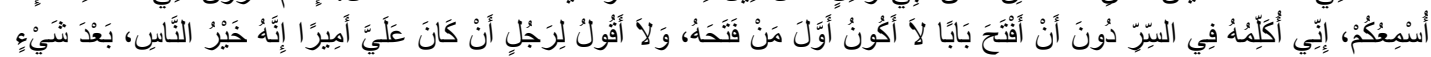

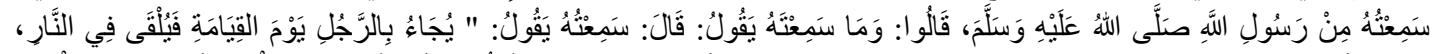

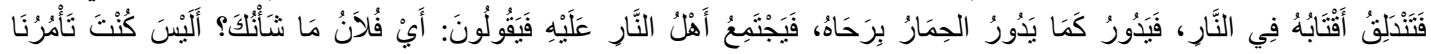

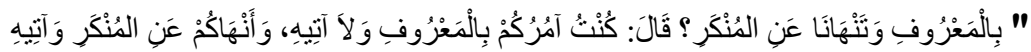

Terjemahan;

Telah bercerita kepada kami 'Ali, telah bercerita kepada kami Sufyan, dari Al A'masy, dari Abu Wa'i berkata; "Dikatakan kepada Usamah; "Seandainya kamu temui fulan ('Utsman bin 'Affan radliallahu 'anhu) lalu kamu berbicara dengannya". Usamah berkata; "Sungguh jika kalian memandang aku tidak berbicara dengannya, selain bahkan kuperdengarkannya kepada kalian semua. Sungguh aku sudah berbicara kepadanya secara rahasia, dan aku tidak membuka suatu pembicaraan yang aku menjadi orang pertama yang membukanya. Aku juga tidak akan mengatakan kepada seseorang yang seandainya dia menjadi pemimpinklu, bahwa dia sebagai manusia yang lebih baik, setelah kudengar dari Rasulullah shallallahu 'alaihi wasallam". Mereka bertanya; "Apa yang kamu dengar dari sabda Beliau 
Shallallahu'alaihiwasallam ". Usamah berkata; "Aku mendengar Beliau bersabda: Pada hari qiyamat akan dihadirkan seseorang yang kemudian dia dilempar ke dalam neraka, isi perutnya keluar dan terburai hingga dia berputar-putar bagaikan seekor keledai yang berputar-putar menarik mesin gilingnya. Maka penduduk neraka berkumpul mengelilinginya seraya berkata; "Wahai fulan, apa yang terjadi denganmu?. Bukankah kamu dahulu orang yang memerintahkan kami berbuat ma'ruf dan melarang kami berbuat munkar?". Orang itu berkata; "Aku memang memerintahkan kalian agar berbuat ma'ruf tapi aku sendiri tidak melaksanakannya dan melarang kalian berbuat munkar, namun malah aku mengerjakannya (M. bin I. Al-Bukhari, n.d.-c)

Imam al-Bukhari menjelaskan tentang orang yang hanya mengajak orang lain mengerjakan kebaikan, tapi dia sendiri tidak mengerjakannya. Dan melarang mereka dari melakukan perbuatan buruk, tapi dia sendiri melakukannya. Maka, Allah mengancam dengan mencampakkan ke dalam neraka bagi siapa saja yang menyuruh berbuat baik tapi dia sendiri tidak mengerjakannya. Dan melarang dari perbuatan munkar tapi dia sendiri mengerjakannya (Al-'Utsaimin, n.d.). Mengajak kepada kebaikan dan melarang dari kejahatan adalah salah satu tugas dan fungsi seorang guru. Jadi, guru harus mengamalkan ilmu yang diajarkannya kepada peserta didik dan hendaklah perkataannya sesuai dengan perbuatannya agar terhindar dari siksaan Allah.

\section{Lemah Lembut dan Kasih Sayang}

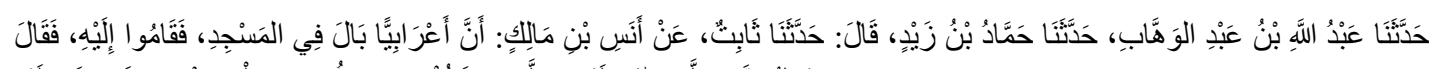

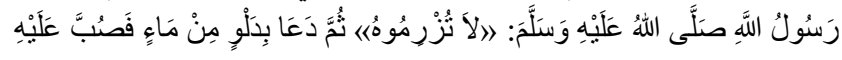

Terjemahan;

Telah menceritakan kepada kami 'Abdullah bin 'Abd al-Wahhab, telah menceritakan kepada kami Hammad bin Zaid, dia berkata, telah menceritakan kepada kami Śabit, dari Anas bin Malik bahwa seorang arab badui kencing di masjid, lalu orangorang mendatanginya, maka Rasulullah saw. bersabda: "Biarkanlah dia". Kemudian Rasulullah saw. meminta diambilkan air lalu air itu disiramkan di atasnya (bekas kencing) (M. bin I. Al-Bukhari, n.d.-d)

Muhammad bin Ismail al-Bukhari menggambarkan bagaimana kelembutan dan kasih sayang yang dimiliki Rasulullah saw kepada umatnya yang merupakan peserta didiknya. Seorang Arab badui melakukan perbuatan yang sangat tidak baik, yaitu buang air kecil di masjid, rumah Allah, tempat beribadah umat Islam. Para sahabat yang melihat kejadian tersebut marah dan hendak menghentikannya. Tapi, 
Rasulullah saw tidak marah dan memerintahkan para sahabatnya untuk membiarkannya hingga selesai. Kemudian, Rasulullah saw. menasehati dan mendidiknya.

Seorang guru harus memiliki sifat lemah lembut dan kasih sayang kepada peserta didiknya. Jika tidak, maka sikap kasar yang merupakan lawan dari sifat lemah lembut dan kasih sayang itu akan menjadi penghalang baginya untuk mencapai tujuan pendidikan. Menurut Asma Hasan Fahmi dalam Ahmad Tafsir, bahwa kasih sayang itu dapat dibagi dua. Pertama, kasih sayang dalam pergaulan, pendidik harus lemah lembut dalam bergaul. Konsep ini mengajarkan agar tatkala menasehati peserta didik yang melakukan kesalahan, pendidik menegurnya dengan cara memberikan penjelasan, bukan dengan cara mencelanya. Kedua, kasih sayang yang diterapkan dalam mengajar. Ini berarti pendidik tidak boleh memaksa peserta didik mempelajari sesuatu yang belum dapat dijangkaunya (Tafsir, 2010).

5. Memperhatikan keadaan peserta didik

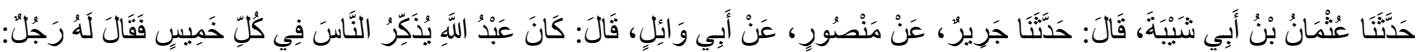

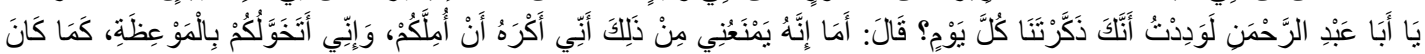

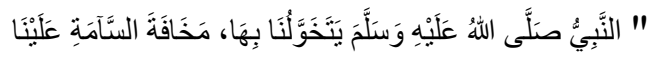

Terjemahan'

Telah menceritakan kepada kami 'Usman bin Abu Syaibah, dia berkata, telah menceritakan kepada kami Jarir, dari Mansur dari Abu Wail, dia berkata, 'bahwa 'Abdullah (Binu Mas'ud) memberi pelajaran kepada orang-orang setiap hari Kamis, kemudian seseorang berkata, 'Wahai Abu 'Abd ar-Rahman, sungguh aku ingin kalau anda memberi pelajaran kepada kami setiap hari'. Dia berkata: "Sungguh aku enggan melakukannya, karena aku takut membuat kalian bosan, dan aku ingin memberi pelajaran kepada kalian sebagaimana Nabi saw. memberi pelajaran kepada kami karena khawatir kebosanan akan menimpa kami"(M. bin I. AlBukhari, n.d.-f).

Muhammad bin Ismail al-Bukhari memberikan informasi bahwa Nabi saw. tidak mengajar para sahabatnya setiap hari, tetapi ada waktu belajar dan ada waktu istirahat. Hal itu dilakukan oleh Nabi saw. untuk menghindari kebosanan peserta didik terhadap pelajaran. Hal ini menunjukkan bahwa Nabi saw. memperhatikan kondisi para sahabat yang merupakan peserta didiknya dalam belajar.

Oleh karena itu, pendidik harus memperhatikan keadaan peserta didiknya karena hal itu sangat membantu terlaksananya pendidikan dan pembelajaran dengan efektif. Dalam dunia pendidikan, hal-hal yang perlu diperhatikan agar 
pendidikan dan pembelajaran berjalan dengan efektif adalah minat, perhatian, kemampuan, dan kondisi jasmani peserta didik. Maka, pendidik jangan sampai memberikan beban pelajaran yang melebihi batas kemampuan peserta didik.

6. Penyabar

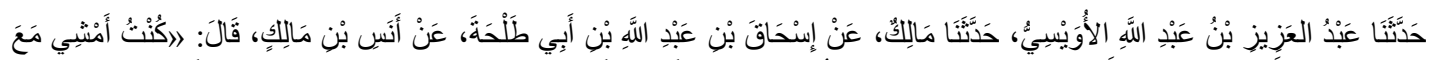

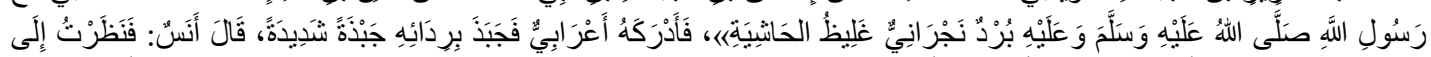

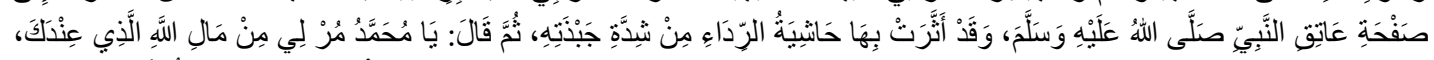

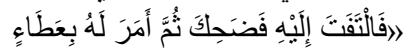

Terjemahan;

Telah menceritakan kepada kami 'Abd al-'Aziz bin 'Abdullah al-Uwaisi, telah menceritakan kepada kami Malik, dari Ishaq bin 'Abdullah, dari Anas bin Malik, 'Aku pernah berjalan bersama Nabi saw. yang ketika itu Nabi saw. mengenakan selendang yang tebal dan kasar buatan Najran. Kemudian seorang arab badui datang lalu menarik Nabi saw. dengan tarikan yang keras hingga aku melihat permukaan pundak Nabi saw. berbekas akibat tarikan yang keras itu. Lalu dia berkata kepada Nabi saw. berkata, 'Perintahkanlah, agar aku diberikan harta Allah yang ada padamu'. Kemudian Nabi saw. memandang kepada orang Arab badui itu dan tertawa. Lalu Nabi saw. memerintahkan agar memberinya (harta) (M. bin I. AlBukhari, n.d.-e)

Muhammad bin Ismail al-Bukhari menjelaskan bagaimana kesabaran Rasulullah saw. terhadap kelakuan buruk Arab Badui kepadanya. Arab Badui itu menarik kerah bajunya dengan keras hingga membekas di lehernya, Rasulullah saw. tidak marah kepadanya dan tidak pula membalas kelakuan buruknya dengan keburukan juga tapi Rasulullah saw. tertawa dan tersenyum kepadanya. Hal ini menunjukkan begitu agungnnya akhlak Rasulullah saw. dan kesabarannya terhadap perbuatan-perbuatan buruk umatnya yang merupakan peserta didiknya kepadanya, Rasulullah saw. tidak membalas perbuatan buruk itu dengan keburukan tapi membalasnya dengan kebaikan.

Maka, hendaklah seorang guru memiliki sifat sabar dan menahan emosinya dalam menjalankan tugasnya sebagai guru karena dia pasti akan mendapati berbagai macam perkara yang tidak dia sukai dari peserta didiknya.

Ada keterkaitan antara sabar dengan pendidikan, ialah seorang guru akan berkomunikasi dengan individu-individu yang memiliki watak dan pemahaman yang berbeda-beda. Di antara mereka ada yang bagus dan ada yang lemah. Di samping kesibukan guru dengan tugas absensi, memeriksa, dan mengajar yang dilakukan 
terus-menerus setiap hari pada waktu jam belajar, ditambah dengan permasalahanpermasalahan siswa yang terjadi berulang kali. Maka, hal ini menuntut guru untuk dapat bersabar dalam menghadapinya. Hilang kesabaran dan melampiaskan emosi bisa menjerumuskan guru pada kesulitan besar, terutama jika hal itu terjadi pada waktu aktivitas belajar mengajar sedang berlangsung.

7. Bersikap Adil dan Tidak Pilih Kasih

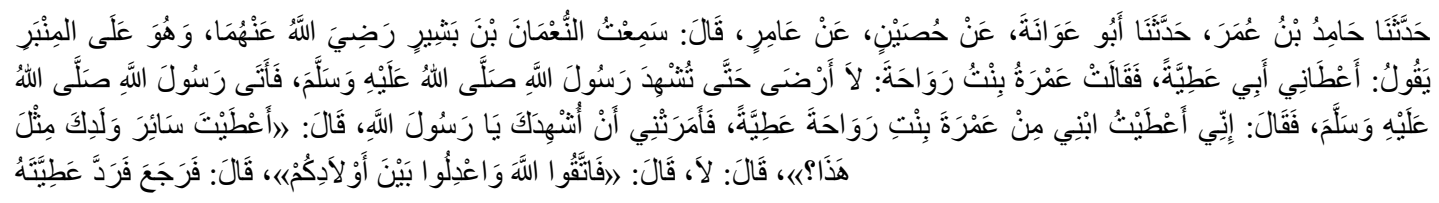

Terjemahan;

Telah menceritakan kepada kami Hamid bin 'Umar, telah menceritakan kepada kami Abu 'Awanah, dari Huśain, dari 'Amir berkata, aku mendengar an-Nu'man bin Basyir berkhutbah diatas mimbar, dia berkata, 'Bapakku memberiku sebuah hadiah (pemberian tanpa imbalan). Maka 'Amrah putri Rawahah berkata, 'Aku tidak rela sampai kamu mempersaksikannya kepada Rasulullah saw..' Maka bapakku menemui Rasulullah saw. dan berkata, 'Aku memberi anakku sebuah hadiah yang berasal dari 'Amrah putri Rawahah, namun dia memerintahkan aku agar aku mempersaksikannya kepada anda, wahai Rasulullah". Rasulullah saw. bertanya: "Apakah semua anakmu kamu beri hadiah seperti ini?". Dia menjawab: Tidak. Beliau bersabda: "Bertakwalah kalian kepada Allah dan berbuat adillah antara anak-anak kalian". An-Nu'man berkata: "Maka dia kembali dan Rasulullah saw. menolak pemberian bapakku" (M. bin I. Al-Bukhari, n.d.-b).

Muhammad bin Ismail al-Bukhari menjelaskan bahwa Nabi saw. dengan tegas memerintahkan para sahabatnya (muridnya) agar berlaku adil terhadap anakanak mereka. Karena, berlaku tidak adil antara mereka akan menimbulkan permusuhan dan saling membenci antara mereka. Hamzah Muhammad Qasim mengatakan bahwa hadits ini merupakan haramnya berlaku tidak adil, dan mengutamakan sebagian mereka (anak-anak) atas sebagian yang lain dapat menimbulkan permusuhan, saling membenci dan pemutusan tali silaturahmi di antara mereka. Seorang guru harus memiliki sifat adil dalam melaksanakan tugasnya sebagai guru agar dia dicintai oleh peserta didiknya dan dapat mentransfer ilmu pengetahuan kepada mereka dengan efektif. 
8. Bertanggungjawab

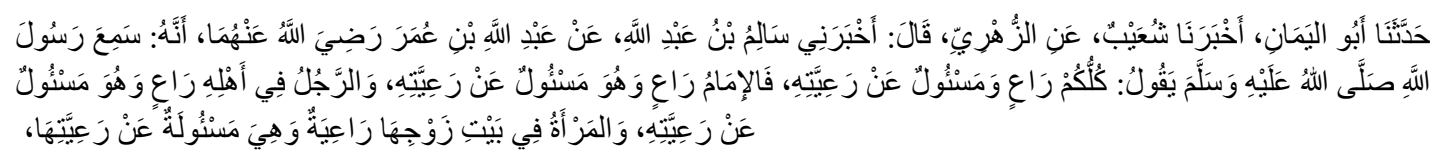

Terjemahan;

Telah menceritakan kepada kami Abu alYaman, telah mengabarkan kepada kami Syu'aib, dari az-Zuhri, dia berkata, telah mengabarkan kepadaku Salim bin 'Abdullah, dari 'Abdullah bin 'Umar, bahwa dia mendengar Rasulullah saw. bersabda: "Setiap kalian adalah pemimpin dan setiap pemimpin akan diminta pertanggung jawaban atas yang dipimpinnya. Imam (kepala Negara) adalah pemimpin yang akan diminta pertanggung jawaban atas rakyatnya. Seorang suami dalam keluarganya adalah pemimpin dan akan diminta pertanggung jawaban atas keluarganya. Seorang isteri adalah pemimpin di dalam urusan rumah tangga suaminya dan akan diminta pertanggung jawaban atas urusan rumah tangga tersebut (M. bin I. Al-Bukhari, n.d.-a)."

Muhammad bin Ismail al-Bukhari meriwayatkan tentang pernyataan Nabi saw. bahwa setiap orang adalah pemimpin, setiap pemimpin akan diminta pertanggung jawaban atas yang dipimpinnya. Kepala rumah tangga adalah pemimpin bagi istri dan anak-anaknya, dan dia akan diminta pertanggung jawaban atas mereka. Maka, seorang kepala rumah tangga berkewajiban memenuhi hak istri dan anak-anaknya, dan termasuk hak mereka adalah mendidik dan mengajari mereka apa-apa yang bermanfaat dan yang tidak bermanfaat bagi mereka.

Selalu merasa bertanggung jawab akan membuat seseorang melaksanakan tugasnya dengan baik. Karena, dia menyadari bahwa dia akan diminta pertanggungjawaban atas tugas-tugasnya tersebut. Begitu juga seharusnya seorang guru, hendaknya selalu merasa bertanggung jawab atas anak didiknya. Hal demikian, sangat membantunya dalam melaksanakan tugasnya sebagai seorang guru dengan sebaik-baiknya. Apabila sifat ini hilang dari seorang guru, maka dia akan menyepelekan hak-hak anak didiknya berupa pengajaran dan perhatian serta penyucian jiwa dan akhlak mereka.

Relevansi Etika Guru Menurut al-Bukhari Terhadap Profesionalitas Guru Pendidikan Agama Islam

1. Keikhlasan

Muhammad bin Ismail al-Bukhari menjelaskan bahwa keikhlasan merupakan syarat diterimanya suatu amalan, dan suatu amalan tidak dikatakan amal shalih 
tanpa keikhlasan. dan keabsahan amalan dan keberadaan konsekuensinya ditentukan oleh niatnya, dan niatlah yang mengarahkan suatu amalan. Dan penyataan ini sangat relevan dengan Undang-Undang RI No. 14 Tahun 2005 tentang Guru dan Dosen, Pasal 7 butir b dalam prinsip Profesionalitas menyatakan bahwa profesi guru dilaksanakan berdasarkan prinsip memiliki komitmen untuk meningkatkan mutu pendidikan, keimanan, ketakwaan, dan akhlak mulia (Departemen Pendidikan Nasional, 2005). Dan pasal 20 butir d, dalam melaksanakan tugas keprofesionalan, guru berkewajiban menjunjung tinggi peraturan perundangundangan, hukum, dan kode etik guru, serta nilai-nilai agama dan etika.

Pernyataan tersebut juga sesuai dalam Undang-Undang Nomor 20 tahun 2003 tentang tujuan pendidikan nasional yaitu, untuk mengembang kekuatan spiritual keagamaan, menjadikan murid beriman dan bertakwa kepada Allah swt, dan berakhlak mulia (Hafid \& Dkk, 2014).

Relevansi etika guru dalam riwayat Muhammad bin Ismail al-Bukhari dengan konsep kepribadian guru yang tertera dalam Undang-Undang Republik Indonesia Nomor 14 tahun 2005 tentang guru dan dosen pasal 7 dan 20 dan Undang-Undang Nomor 20 tahun 2003 tentang tujuan pendidikan nasional yakni, sama-sama menghendaki seorang guru dalam mengajar berlandaskan pada nilai-nilai agama.

2. Memiliki Ilmu

Muhammad bin Ismail al-Bukhari juga menjelaskan bahwa orang yang berfatwa dan mengajar harus memiliki ilmu. Termasuk dalam hal ini adalah seorang guru, guru haruslah orang yang berilmu. Jika seorang guru tidak berilmu tentu peserta didik yang diajarnya akan sesat. Maka, seorang guru hendaknya selalu belajar dan menambah ilmu pengetahuannya dan mampu mencerdaskan orang lain dengan suatu ilmu pengetahuan.

Dalam Undang-Undang Guru dan Dosen pasal 7 butir g tentang prinsip profesionalitas yakni, memiliki kesempatan untuk mengembangkan keprofesionalan secara berkelanjutan dengan belajar sepanjang hayat (Life Long Education) (Tim Penyusun, 2005).

Relevansi etika guru menurut Muhammad bin Ismail al-Bukhari al-Bukhari dengan konsep kepribadian guru yang tertera dalam Undang-Undang Guru dan dosen Pasal 7 butir $g$ tersebut yakni, menghendaki seorang guru selalu meningkatkan mutu pengetahun dan pendidikannya . 


\section{Konsekuen}

Muhammad bin Ismail al-Bukhari menjelaskan tentang peringatan keras bagi orang yang hanya mengajak orang lain mengerjakan kebaikan, tapi dia sendiri tidak mengerjakannya. Dan melarang mereka dari melakukan perbuatan buruk, tapi dia sendiri melakukannya.

Konsep guru yang diriwayatkan oleh Muhammad bin Ismail al-Bukhari ini sangat relevan dengan konsep kepribadian guru dalam Pemendiknas Nomor 16 tahun 2007, yaitu menampilkan diri sebagai pribadi yang jujur, mantap dan memiliki kepribadian yang dewasa, arif, berwibawa, tanggungjawab, berakhlak mulia dan menjadi teladan, serta religious (Majid, 2013).

4. Lemah Lembut

Muhammad bin Ismail al-Bukhari dalam Sahihnya menggambarkan bagaimana kelembutan dan kasih sayang Rasulullah saw. kepada umatnya yang merupakan peserta anak didiknya, sehingga apa yang diajarkannya terserap ke dalam hati peserta didiknya dan membuatnya terkesan dengan senang hati dan lapang dada menerimanya.

Undang Undang Guru dan Dosen pasal 20 butir d dalam melaksanakan tugas keprofesionalan, guru berkewajiban menjunjung tinggi peraturan perundangundangan, hukum, dan kode etik guru, serta nilai-nilai agama dan etika. Dan Pasal 7 butir b. bahwa seorang guru memiliki komitmen untuk meningkatkan mutu pendidikan, keimanan, ketakwaan, dan akhlak mulia (Tim Penyusun, 2005).

Riwayat Muhammad bin Ismail al-Bukhari sangat relevansi dengan konsep kepribadian guru yang tertera dalam Undang Undang Guru dan Dosen Nomor 16 Pasal 7 butir b yakni, sama-sama berbicara tentang akhlak mulia. Dan Riwayat Muhammad bin Ismail al-Bukhari juga sesuai dengan penjelasan tentang kompetensi kepribadian guru, dalam Undang Undang Nomor 16 Tahun 2007, bahwa seorang guru harus memiliki kepribadian yang mantap, stabil, dewasa, arif dan bijaksana, berwibawa, berakhlak mulia, menjadi teladan bagi peserta didik dan masyarakat, mengevaluasi kinerja sendiri, dan mengembangkan diri secara berkelanjutan (Tim Penyusun, 2007).

5. Memperhatikan Keadaan Peserta Didik

Muhammad bin Ismail al-Bukhari memberikan informasi dalam Sahihnya, bahwa Nabi saw. tidak mengajar para sahabatnya setiap hari, tetapi ada waktu 
belajar dan ada waktu istirahat. Hal itu dilakukan oleh Nabi saw. untuk menghindari kebosanan peserta didik terhadap pelajaran sehingga sangat membantu terlaksananya pendidikan dan pembelajaran yang efektif. Hal ini juga menunjukkan bahwa Nabi saw. memperhatikan kondisi para sahabat yang merupakan peserta didiknya dalam belajar.

Undang undang guru pasal 20 butir a merencanakan pembelajaran, melaksanakan proses pembelajaran yang bermutu, serta menilai dan mengevaluasi hasil pembelajaran (Tim Penyusun, 2005).

Riwayat Muhammad bin Ismail al-Bukhari ini sangat relevansi dengan konsep kepribadian guru yang tertera dalam Undang Undang Guru pasal 20 butir a, yaitu sama-sama menjelaskan bahwa syarat seorang guru harus berkompeten dalam materi ajarnya dan mengevaluasi pembelajarannya.

\section{Penyabar}

Muhammad bin Ismail al-Bukhari menjelaskan bagaimana kesabaran Rasulullah saw. terhadap kelakuan buruk Arab Badui kepadanya. Arab Badui itu menarik kerah baju Rasulullah dengan keras hingga membekas di lehernya, Rasulullah saw. tidak marah kepadanya dan tidak pula membalas kelakuan buruknya dengan keburukan serupa, justru Rasulullah saw. tertawa dan tersenyum kepadanya. Hal ini menunjukkan begitu agungnnya akhlak Rasulullah saw. dan kesabarannya terhadap perbuatan-perbuatan yang tidak terpuji yang merupakan peserta didiknya, Rasulullah saw tidak membalas perbuatan buruk itu dengan keburukan tapi membalasnya dengan kebaikan.

Riwayat Muhammad bin Ismail al-Bukhari sangat relevansi dengan konsep kepribadian guru yang tertera dalam Undang Undang Guru dan Dosen Nomor 16 Pasal 7 butir b yakni, sama-sama berbicara tentang akhlak mulia. Dan Riwayat Muhammad bin Ismail al-Bukhari juga sesuai dengan penjelasan tentang kompetensi kepribadian guru, dalam Undang Undang Nomor 16 Tahun 2007, bahwa seorang guru harus memiliki kepribadian yang mantap, stabil, dewasa, arif dan bijaksana, berwibawa, berakhlak mulia, menjadi teladan bagi peserta didik dan masyarakat, mengevaluasi kinerja sendiri, dan mengembangkan diri secara berkelanjutan.

\section{Bersikap Adil}

Muhammad bin Ismail al-Bukhari menjelaskan bahwa riwayat tersebut sangat menekankan kepada para orang tua agar berlaku adil kepada anak-anak 
mereka karena orang tua merupakan guru pertama bagi anak-anaknya. Dan di dalam konteks pendidikan, guru adalah orang tua bagi peserta didik. Dengan demikian, guru juga wajib berlaku adil dalam berbagai hal terhadap peserta didiknya.

Undang Undang Guru dan Dosen Pasal 20 butir c. Seorang guru berkewajiban bertindak objektif dan tidak diskriminatif atas dasar pertimbangan jenis kelamin, agama, suku, ras, dan kondisi fisik tertentu, atau latar belakang keluarga, dan status sosial ekonomi peserta didik dalam pembelajaran.

Riwayat Muhammad bin Ismail al-Bukhari ini sangat relevan terhadap konsep komptesi guru dalam Undang Undang Guru dan Dosen pasal 20 butir c yakni, hendaklah seorang guru bertindak objektif dan tidak diskriminatif terhadap murid. Dan relevan yang ditunjukkan dengan kompetensi sosial guru dalam Undangundang Nomor 16 Tahun 2007, yaitu bertindak dan bersikap secara objektif dan tidak diskriminatif. Serta Kode Etik Guru Indonesia PGRI XX tahun 2008, yaitu "Guru tidak boleh melakukan tindakan dan mengeluarkan pendapat yang akan merendahkan martabat profesionalnya."

\section{Bertanggung Jawab}

Muhammad bin Ismail al-Bukhari menjelaskan dalam pernyataan Nabi saw. bahwa setiap orang adalah pemimpin, setiap pemimpin akan diminta pertanggung jawaban atas yang dipimpinnya. Kepala rumah tangga adalah pemimpin bagi istri dan anak-anaknya, dan dia akan diminta pertanggung jawaban atas mereka. Maka, seorang kepala rumah tangga berkewajiban memenuhi hak istri dan anak-anaknya, dan termasuk hak mereka adalah mendidik dan mengajari mereka apa-apa yang bermanfaat dan yang tidak bermanfaat bagi mereka. Maka seorang guru pun bertanggungjawab atas anak didiknya.

Riwayat Muhammad bin Ismail al-Bukhari ini sangat relevan terhadap Undang Undang Guru dan Dosen pasal 7 butir e dalam melaksanakan tugas keprofesionalan, guru memiliki tanggung jawab atas pelaksanaan tugas keprofesionalan. Guru profesional dituntut memiliki kompetensi-kompetensi khusus.

Dengan melaksanakan kewajiban-kewajiban sebagaimana diamanatkan oleh undang-undang tersebut, maka seorang guru akan tetap eksis di tengah-tengah perkembangan ilmu pengetahuan dan teknologi yang semakin pesat. Demikian pula 
para peserta didik akan semakin hormat kepadanya karena mereka melihat guru mereka sebagai sosok yang senantiasa dapat ditiru dan digugu.

\section{Simpulan}

Berdasarkan hasil penelitian dan analisa yang telah penulis uraikan terdahulu mengenai konsep etika guru dalam kitab Sahih al-Bukhari karya Muhammad bin Ismail al-Bukhari, maka dapat disimpulkan bahwa: Pertama, riwayat Muhammad bin Ismail al-Bukhari dalam karyanya Sahih al-Bukahri, mengangkat nilai-nilai etika dan moral yang mutlak harus dimiliki oleh guru profesional. Karena segala gerak langkah seorang guru akan dinilai oleh lingkungan, terutama oleh peserta didiknya. Di antara etika yang harus dijaga seperti yang ditekankan oleh Muhammad bin Ismail alBukhari dalam Sahihnya adalah keikhlasan, berilmu, konsukuen, kasih sayang, memperhatikan keadaan peserta didik, penyabar, bersikap adil dan tidak diskriminatif di antara anak didiknya dan bertanggungjawab.

Konsep etika guru dalam kitab Shahih al-Bukhari sejalan dengan peraturan pemerintah yang tertuang dalam Undang-undang Republik Indonesia No. 14 Tahun. 2005 Tentang Guru dan Dosen. Dalam hal ini, prinsip Profesionalitas menyatakan profesi guru dilaksanakan berdasarkan prinsip memiliki komitmen untuk meningkatkan mutu pendidikan, keimanan, ketakwaan, dan akhlak mulia.

\section{Referensi}

Al-`Utsaimin, M. bin S. bin M. (n.d.). Syarh Riyadh al-Shalihin, Jilid II. Dar al-Wathn.

Al-Asqalany, A. al-F. A. bin A. bin H. (n.d.). Fath al-Bari Syarh Sahih al-Bukhari, Jilid I. Dar al-Ma'rifah.

Al-Bantani, M. N. bin U. al-J. (n.d.). Bahjat al-Wasaail bi Syarh al-Masaail. Musthafa alBabi al-Halabi wa Auladuh.

Al-Barr, Y. bin A. bin M. bin 'Abd. (n.d.). Sahih Jaami' Bayan al-'Ilmi wa Fadlihi. Maktabah Dar Ibn Taimiyah.

Al-Bukhari, M. bin I. (n.d.-a). Sahih al-Bukhari, No. Hadis. 2409, Juz III.

Al-Bukhari, M. bin I. (n.d.-b). Sahih al-Bukhari, No. Hadis. 2587, Juz III.

Al-Bukhari, M. bin I. (n.d.-c). Sahih al-Bukhari, No. Hadis. 3267, Juz IV.

Al-Bukhari, M. bin I. (n.d.-d). Sahih al-Bukhari, No. Hadis. 6025, Juz VIII.

Al-Bukhari, M. bin I. (n.d.-e). Sahih al-Bukhari, No. Hadis. 6088, Juz IX. 
Al-Bukhari, M. bin I. (n.d.-f). Sahih al-Bukhari, No. Hadis. 70, Juz I.

Al-Bukhari, M. bin I. bin I. al-M. (2002). Sahih al-Bukhari, No. Hadis. 1. Dar Ibnu Katsir.

Al-Ghazali, A. H. M. bin M. (2005). Ihyâ 'Ulum al-Din. Dar Ibn Hazm.

Al-Jawziyyah, A. A. M. bin A. B. I. Q. (n.d.). I'lām al-Muwaqi'īn 'an Rabb al-'Ālamin, Takhrij: Abu Umar Ahmad Abdullah, Jilid 4. Dar al-Jawzi,.

Al-Khattabi, A. S. A. bin M. (1932). Ma'alim al-Sunan, Tahqiq; Muhammad Raghib alThabbakh, Juz III. al-Mathba'ah al-Ilmiyah.

Al-Subki, A. al-W. (n.d.). Tabaqat asy-Syafi'iyyah al-Kubra, tahqiq 'Abd al-Fattah alHalw dan Muhammad at-Tanahi, jilid II. Dar Ihya' al-Kutub al-'Arabiyyah.

Al-Tirmidzi, A. I. M. bin I. bin S. (1987). Sunan al-Tirmidzi, No. 2682, Tahqiq: Kamal Yusuf al-Hut, Jilid 5. Dar al-Kutub al-Ilmiyah.

Ash'ari, H. (n.d.). Adab al-'Alim wa al-Muta'llim fima Yahtaju ilaihi al-Muta'allim fi Ahwal Ta'limih wa ma Yatawaqqafu 'alaihi al-Mu'allim fi Maqamati Ta'limih. Maktabah al-Turath al-Islam.

Daeng Pawero, A. M. V. (2018). Analisis Kritis Kebijakan Kurikulum Antara KBK, KTSP, dan K-13. Jurnal Ilmiah Iqra', 12(1), 42. https://doi.org/10.30984/jii.v12i1.889

Departemen Pendidikan Nasional. (2005). Undang-Undang RI No. 14 Tahun 2005 tentang Guru dan Dosen. Depdiknas.

Hafid, A., \& Dkk. (2014). Konsep Dasar Ilmu Pendidikan. Alfabeta.

Majid, A. (2013). Belajar dan Pembelajaran PAI. Remaja Rosdakarya.

Munawir, \& Al-Bisri. (1999). Kamus Al-Bisri. Pustaka Progressif,.

Soetari, E. (2008). Ilmu Hadits Kajian Riwayat \& Dirayah. CV. Mimbar Pustaka.

Suyitno. (2006). Tokoh-Tokoh Pendidikan Dunia. Pascasarjana Universitas Pendidikan Islam.

Tafsir, A. (2010). Ilmu Pendidikan dalam Perspektif Islam. Remaja Rosdakarya.

Tim Penyusun. (2005). UU RI Nomor 14 Tahun 2005 Tentang Guru dan Dosen.

Tim Penyusun. (2007). Peraturan Menteri Pendidikan Nasional Nomor 16 Tahun 2007 tentang Standar Kualifikasi Akademik dan Kompetensi Guru. Kemendiknas.

Ulwan, A. N. (2008). Tarbiyah al-Aulad fi al-Islam. Dar al-Salaam.

Zed, M. (2008). Metode Penelitian Kepustakaan. Yayasan Obor Indonesia. 